\title{
Minimum requirements for wildfire investigations
}

\author{
by Paul M. Woodard ${ }^{1}$
}

\begin{abstract}
Provincial forest management agencies across Canada are attempting to recover suppression costs plus losses to real property due to human-caused fires when negligence is involved. These agencies are responsible for investigating these fires, and they commonly restrict all access to the fire origin area. These agencies commonly employ well trained fire investigators, who are well aware of standards for documenting wildland fires. However, in many cases, the quality of the investigations is poor, and the cost of finding this additional information is great. In this paper, I identify the minimum information required before an investigation file should be considered complete and charges can be laid.
\end{abstract}

Key words: wildland fire, investigation, reports, litigation, standards

\section{RÉSUMÉ}

Les agences provinciales de tout le Canada chargées de l'aménagement forestier tentent de récupérer les frais de suppression ainsi que les pertes en valeur immobilière découlant de feux de forêt provoqués par négligence humaine. Ces agences ont la responsabilité d’enquêter sur ces feux et interdisent habituellement l'accès à la zone dorigine des feux. Ces agences font appel régulièrement à des inspecteurs spécialement formés dans le domaine qui sont bien informés des normes entourant la documentation des feux sur territoire à protection limitée. Cependant, dans plusieurs cas, la qualité des enquêtes est faible et le coût de recherche de l'information additionnelle est élevé. Dans cet article, j’identifie l'information minimale requise pour qu'un dossier d’enquête soit considéré comme complet et que des accusations soient portées.

Mots clés : feu sur territoire à protection limitée, enquête, rapports, litige, normes

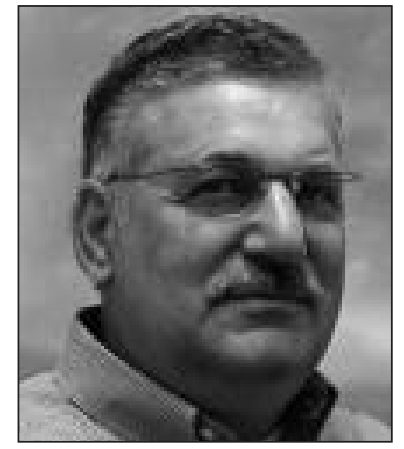

Paul M. Woodard

\section{Introduction}

It is becoming more common for protection agencies to try to recover wildland fire suppression costs and losses to real property. To do this, protection agencies are spending more time investigating the causes of wildland fires and when warranted charging persons or industries believed to be responsible.

The techniques used for investigating wildland fires are well documented and many protection agencies in Canada have their own investigation handbooks, procedures, and reporting guidelines. This is certainly the case in Alberta, Ontario, and British Columbia. In the United States, the National Wildfire Coordinating Group has many manuals and training programs that describe how investigations should proceed (Anonymous 2004). In addition there are a number of independent resources such as a book by Ford (1987), and the standards outlined in NFPA 921 of the National Fire Protection Association (2004). In general, there is no shortage of information on what should be done during a wildland fire investigation but at present there is little information for those not involved in fire investigations as to what they should expect in terms of evidence when faced with charges for fire-related costs or damages.

It is common for the first fire-related responders to restrict access to the "believed" origin area. In fact, this procedure is required as part of a high-quality investigation as it insures evidence is not disturbed, contaminated, or destroyed. Generally, soon after the fire origin is secured it is physically inspected, photographed, and on-site evidence is interpreted by the responsible protection agency employee or their contractor. It has been my experience, over the last twenty years, that the information needed to asses the specific cause of most fires is not presented to the individual or company alleged to be responsible. The absence of this information adds an unneeded and often unjustified cost for industries or private individuals. The purpose of the paper is to identify what evidence should be available and produced at the time of invoicing or laying charges to insure a proper independent evaluation and determination of responsibility can be made by the party alleged to be responsible for causing the fire.

\section{What Is Needed \\ Location}

The precise location of the believed fire origin area or site is required and that information should be reported by latitude and longitude. Global Positioning System equipment must be used to geographically locate every wildland fire origin site when it is known. Other identifiers, such as Township, Range,

\footnotetext{
${ }_{1}^{1}$ Department of Renewable Resources, 751 General Services Building, University of Alberta, Edmonton, Alberta T6K 1Y3. E-mail: paul.woodard@ualberta.ca
} 
Section and Quarter Section, are not sufficiently precise to allow follow-up investigators to visually inspect the exact origin site.

\section{Time/date}

It is imperative that wildland fire records show the time and date the fire started-if known-or was discovered. If possible, the person responsible for reporting the fire should be identified and the phone number for that individual should be made available.

\section{Size}

The size of the fire at the time it was first observed should be recorded by the agency initiating the wildland fire report record. This estimate of size need only be relatively accurate but that type of information is often extremely helpful. A relative size estimate at an estimated time by an untrained individual is often as helpful as one involving estimated measurements. For example, knowing the fire at discovery was as large as a campfire, a sheet of plywood, an automobile, or a football field is very helpful. These are objects to which people can relate. All future accounts of fire size as reported by the investigation team should include actual measurements.

\section{Weather/lightning}

It is important to know the present and past weather for the fire origin area as it has a direct impact on how the fire might have started and how fast it spread. Weather information is almost always available in most wildland fire investigation files. However, often, only the records from the "nearest" weather station are included. For my purposes, weather information from one station, even if it is very close to the fire origin is inadequate because the weather instruments at that station may be in need of servicing or the weather station site itself may not be properly maintained (Turner and Lawson 1984). Weather data from any station should be evaluated using data from adjacent stations so I like to have data from many weather stations. If available, I use data from public stations such as those maintained by Environment Canada and Parks Canada to validate data from provincial stations.

The weather data should include information pertaining to temperature, relative humidity, rainfall, wind speed, and wind direction. I appreciate having the 30-day pre-fire weather data from a variety of stations to analyze.

The location of the weather stations in an area is not often readily available to private fire investigators. However, if these other data sets are to be of maximum value, we need to know where these stations are located relative to the fire origin area. To that end, we need the GPS coordinates for all adjacent weather stations in the area. With this information, we can determine the distance and directions these stations are from the fire origin. In addition, we can determine the elevation of these stations relative to that of the fire origin area.

Many provincial agencies also maintain lightning location detection systems that will produce daily maps of strike occurrence by date and location. This information is also important and should be included in any fire investigation files.

All Canadian wildland protection agencies determine and maintain records pertaining to the Canadian Forest Fire Weather Index System (CFFWIS) (Van Wagner 1987). The CFFWIS information is used to keep track of the moisture status of the various levels of downed and dead organic fuels in the upper soil profiles. This system serves as the record of wetting and drying in the area, which allows fire behaviour analysts and fire investigators to better interpret fire cause and behaviour. The CFFWIS codes and indices produced in the fire investigation file are usually computed from the weather reading taken at the weather station nearest to the origin area. Again, having weather data from a number of weather stations allows the expert consultant to better evaluate the evidence upon which management decisions were made.

\section{Witnesses}

Many fires are witnessed by a number of individuals at various stages of development. Information from these individuals can be most useful in determining cause. Understanding this fact, most protection agencies take statements from witnesses. However, for these statements to be of legal value they must be signed, dated, and witnessed in accordance with wellknown evidence gathering procedures.

\section{History of fire occurrence in the area}

Wildland fire occurrence is sometimes related to on-going fires or to reoccurring ignitions. Knowing the current fire activity will enable the expert for the defendant to determine if the fire under question was started by an existing fire. Knowing the historical fire occurrence for an area by date, time, location, and suspected cause may reveal a historical problem with an arsonist, a railway company, a utility company, or some fire prone recreational activity. All investigation reports should include the current and historical fire occurrence for the management area where the contested fire started.

\section{The fire investigation}

The investigation report should include the date and time the fire investigation was initiated. The report should also include the name(s) of the individual(s) who investigated the fire, the methods used in the investigation, which simply could be satisfied by including a statement in the method section of the report that says "the fire investigation followed procedures and protocols outlined in NFPA 921," and copies of all photographs taken while at the scene.

\section{Photos}

Lastly, it would save much time if pre-burn aerial photos, stereo pairs, of the origin area were included in the report. As well, many birddog officers, initial attack crew leaders, and detection aircraft personnel carry cameras for the purpose of documenting fires upon arrival. These and any other photos used to make final determinations of cause should be included in the investigation file.

\section{Conclusion}

In Canada, the cost of practising forestry on public land is increasing while profits are shrinking. It is common for governments across Canada to seek restitution for human-caused fire damage to provincial resources when it can be shown that these fires were caused by negligence. I think it is well understood by forest users that they accept responsibility for their actions while operating in the forests of Canada. They are prepared to pay for damages that result as part of their management operations. 
Much of the cost of determining responsibility for fire damages can be attributed to poor information. When a forest industry or private individual has been charged with starting a fire and the information identified above is missing there can be a significant cost to determining this information. These costs can significantly impact on the profitability of these local industries and this added burden is not justified. Additionally, incomplete reports also add to Provincial costs. I assert that when individual wildland fire investigators fail to produce high-quality, professional investigations, improper decisions are made that cost all parties. In short, everybody suffers as once all of the facts are properly uncovered it may be shown that charging local industries or individuals was not justified.

Lastly, I would suggest that individuals who produce unprofessional fire investigation reports should be reported to their professional college or association. These organizations have a responsibility to maintain standards of practice in all aspects of forestry.

\section{References}

Anonymous. 2004. NWCG Fireline Handbook. Chapter 14. pp. 305-318. NWCG Handbook 3. National Interagency Fire Center, Boise, ID.

Ford, R.T. 1987. Investigation of vegetation fires. Fire Scene Investigations, Madison Ave., Fresno, CA. 69 p.

National Fire Protection Association. 2004. NFPA 921 - Guide for fire and explosion investigations, 2004 Edition. NFPA, Batterymarch, Quincy, MA.

Turner J.A. and B.D. Lawson. 1978. Weather in the Canadian forest fire danger rating system. Environment Canada, Canadian Forestry Service, Information Report BC-X-177. 40 p.

Van Wagner, C.E. 1987. Development and structure of the Canadian forest fire weather index system. Environment Canada, Canadian Forestry Service, Forest Technology Report 35. Ottawa. 37 p. 